\title{
THE THIRD EUROPEAN CONGRESS OF CARDIOLOGY
}

In the spacious halls of the Palazzo dei Congressi, the Third European Congress of Cardiology was opened in Rome on September 18, 1960. It was a memorable and impressive gathering for the great numbers of cardiologists, many with their wives, who had converged upon Rome in weather that was at first oppressively warm. At the Opening Ceremony, addresses were given by the Principal of the University of Rome; by Dr. Evan Bedford, the President of the European Society; by Professor Gustav Nylin; and by Professor Luigi Condorelli, the President of the Congress. Three distinguished non-European visitors also spoke: Dr. Paul White, Professor Ignacio Chavez, and Dr. J. K. Maddox.

The ever-increasing interest in cardiology and its widening medical and social influence was reflected in the attendance, which has increased with each Congress since the First European meeting in London in 1952. Cardiologists arrived from 25 European countries and the world-wide attraction that such a meeting exercises was shown by the attendance of representatives from 16 nonEuropean countries, including many notable figures from the U.S.A. It was encouraging to receive visitors from the U.S.S.R., Poland, Czechoslovakia, and Hungary.

The task faced by the organizers of the congress was no light one when the standards of excellence set by the preceding congresses are remembered. Professor Condorelli's achievement in planning and co-ordinating all the activities, scientific and social, of perhaps 1500 visitors is therefore a remarkable one. Naturally Dr. Vittorio Puddu, as Secretary General, and Dr. Antonio Strano as Secretary have borne an important share of the administrative work. The Congress owes to Mrs. Condorelli and her Committee a debt of gratitude for the excellence of the arrangements made for sight seeing and for the many social occasions that added so much to the enjoyment of the visit to Rome.

One of the most difficult problems that has to be met by the organizing body of such a congress is the great number of communications which necessitate the concurrent use of several halls (five at Rome). Members had necessarily to choose certain sections to the exclusion of several others. This difficulty was met as well as possible in the circumstances by grouping papers in particular categories, but leaving the discussions on each paper till the end of the session and the irregular timing owing to the speakers who failed to turn up lost us some of this advantage. The solution for the future, as the meetings increase even more in size, must be limitation in the number of papers accepted. To try to enumerate the subjects dealt with at the sessions would be to cover the whole field of cardiology, but perhaps the symposia on coronary circulation, extra-corporeal circulation, cardio-respiratory insufficiency, and the ætiology of congenital heart disease, should receive special mention. In a masterly lecture, Evan Bedford surveyed the history of clinical cardiology, and upon this he based his plea that elaborate methods of investigation must supplement and never replace basic clinical methods. The challenging address by Professor Lenègre dealt with the problems to be faced in developing cardiological research and teaching; lack of uniformity in pathological and pharmacological terms remained an obstacle; he was concerned also with the social impact of cardiology and the bearing of Congresses upon the World Health Organization. Professor Condorelli reviewed the vast field of sensitivity of the vascular apparatus and the mechanisms by which these control the circulation. Later, on the last morning, he brought the Congress to a close with an address of philosophic distinction and moving eloquence.

At the General Assembly of the European Society of Cardiology recommendations were made about the officers of the Society and these were later confirmed at the final session. On the 
retirement of Evan Bedford from the Presidency, Lenègre was unanimously elected to succeed him. Van Dooren and Mahaim were re-elected with acclaim as Secretary-General and Treasurer respectively. As Members of the Council to represent Great Britain, Shirley Smith and Mounsey were elected. It was decided that the Fourth European Congress of Cardiology should be held in Prague in 1964.

The social occasions of this Congress will not readily be forgotten. Fabulous ancient buildings and open-air terraces, museums and galleries of ageless antiquity, stately cloisters and statuary, and formal gardens with illuminated fountains are among many kaleidoscopic recollections, not to mention the refreshments and the gay throngs in the warm Roman night.

The Congress of 1960 now fades into the past with its memories of old friendships renewed and new friendships begun. To all it must have brought stimulating thought and experiences. Moreover, it cannot be doubted that through the innumerable international contacts encouraged by the scientific and social life of the Congress, greater mutual understanding and wisdom and goodwill must be generated among the participants. All are working towards the same ends-the alleviation of heart disease and the furtherance of the science of cardiology. 